\title{
Social Justice, Participation and School during the COVID-19-The International Project Gira por la Infancia
}

\author{
Antonio Salvador Jiménez Hernández (D), Jorge Cáceres-Muñoz (D) and Miguel Martín-Sánchez *(D) \\ Department of Education Sciences, Teacher Training College, University of Extremadura, 10003 Cáceres, Spain; \\ ajimenez14@unex.es (A.S.J.H.); jorgecm@unex.es (J.C.-M.) \\ * Correspondence: miguelmartin@unex.es
}

Citation: Jiménez Hernández, A.S.; Cáceres-Muñoz, J.; Martín-Sánchez, M. Social Justice, Participation and School during the COVID-19-The International Project Gira por la Infancia. Sustainability 2021, 13, 2704. https://doi.org/10.3390/su13052704

Academic Editor: Eloy

López Meneses

Received: 14 January 2021

Accepted: 26 February 2021

Published: 3 March 2021

Publisher's Note: MDPI stays neutral with regard to jurisdictional claims in published maps and institutional affiliations.

Copyright: (c) 2021 by the authors. Licensee MDPI, Basel, Switzerland. This article is an open access article distributed under the terms and conditions of the Creative Commons Attribution (CC BY) license (https:// creativecommons.org/licenses/by/ $4.0 /)$.

\begin{abstract}
The purpose of this article is to present the data which have been obtained in a research project on education during coronavirus disease 2019 (COVID-19) in the framework of the international project Gira por la Infancia 2020. The aim was to construct a critical, active, and participatory citizenship. The method used has been the pedagogical hermeneutic in which the qualitative analysis of data was preceded by a process of child participation which allowed the analysis of the opinions of 6867 children and adolescents from 22 countries and 3 continents. The results present the children's thinking about the closure of schools, the alternative teaching carried out, the role of teachers and families, and on the return of the "new school" with the health protocols. This work provides the children's view on the measures of social distancing and massive school closures. However, without doubt, it also shows children's and adolescents' potential to empower themselves in complex situations which put the world's schools in an unprecedented crisis. In addition, it shows the opportunity to take into consideration a joint construction of a society from the germ of its citizenship: children.
\end{abstract}

Keywords: COVID-19; school; childhood; adolescence; citizenship; participation; education; social justice

\section{Introduction}

The coronavirus disease 2019 (COVID-19) pandemic is generating worldwide social, political, economic, and educational scenarios which are rare so far. However, perhaps one of the greatest consequences caused by the severe acute respiratory syndrome coronavirus 2 (SARS-CoV-2) virus is in the school environment, specifically the educational inequality produced by the closure of schools [1] and virtual teaching as an alternative modality to face-to-face. In this sense, Cáceres, Jiménez, and Martín explain that "the consequences of the pandemic caused by the Covid-19 and which is forcing the competent authorities to close the schools is taking away the possibilities of access to optimal levels of educational development to many students around the world ... If before the pandemic there was social inequality, which the school fought against with better or worse results through programs of reinforcement, follow-up, scholarships, compensation, assistance, teachers committed in person, etc., now, that is being lost, aggravating even more the social gap and injustice" [2] (p. 215). COVID-19 gave rise to an educational and social displacement, a dispersal of the child and of the adult in front of the child, when quarantine changed the times and spaces of the school. As a result, it reinvented a new educational scenario and reconfigured the main socio-educational institutions such as the family and the school [3].

According to UNESCO, one billion students, two-thirds of the world's student population faces school closures or uncertainty [4]. Never before have the difficulties of access to education and to the social space constituted by the school generated so much expectation and confusion. Families need to reconcile work and family life so that their children can attend school, and governments consider that it is impossible to compensate parents for not attending work and caring for their children at home $[5,6]$. 
Although the future seems unexplored, the teachings of the past serve us to face this uncertain future with some guarantee. COVID-19 has demonstrated that it is not only a health phenomenon, but also a social, political, emotional, and economic one, which has had a strong impact on the educational field and has increased the digital and social gap. As a result, it endangers the right to participation and education [7]. In the midst of this crossroads, a worldwide debate is opening, questioning the value of schooling in the times of COVID-19. Undoubtedly, the pandemic has meant an important change in schools, teachers, teaching methods, and, of course, students [8-10], a change so drastic which is still being evaluated and that will take a long time to check and calibrate its true effects. In this regard, is the school truly prepared to respond to its students in times of pandemic? Why has almost everything changed and why does the school remain the same? According to Tonucci, "it is not hard to imagine that everything has changed. This is the starting point. If everything has changed, the school can't stay the same. The contradiction which I find is that the school wants to show that it can continue as before and it is still an institution of classes and homework, where the only thing that has changed is the environment: instead of being face-to-face, it is virtual". [11]. Needless to say, education is referred to as the fundamental object of the school. In this sense, the educational curriculum continues to be implemented as if nothing has happened. While scientists around the world, in all specialties, have begun researching the SARS-CoV-2 virus and its consequences, the school continues to teach the content set forth in the program, as if there was not any pandemic. Is the school missing its opportunity to transform, or does it think it is not necessary? In the words of Livari, Sharma, and Ventä “it has been recognized that schools and children's education must undergo a broad digital transformation in order to meet the needs of the young generation and their digitalized future. The COVID-19 pandemic has suddenly forced schools and education to undertake such transformation." [12] (p. 2). Obviously, it alludes to that part of the planet which has the means to carry out such transformation, but what about that other part which does not have the necessary resources such as computers and Internet access? The social and economic crisis arising from the pandemic is further widening the already existing digital gap between developed and developing countries [13] This crisis has relentlessly demonstrated that there is a multi-speed world where the richest countries have been able to adapt better to the crisis, and where the poorest have been left far behind. If there were social justice issues before SARS-CoV-2, the pandemic has magnified them and shown them in all their severity.

The change which the school needs must be addressed through a process led by the entire social community, but, in particular, students have to be listened to. The school that claims to be inclusive should not exclude anyone from the beginning to the end. It has become evident that the pandemic has directly affected the right to education, understood not only as access to instruction but, mainly, as a right which guarantees quality education and an inclusive process that guarantees social justice [14]. The Convention on the Rights of the Child specifically states in Article 12.1. "States Parties shall assure to the child who is capable of forming his or her own views the right to express those views freely in all matters affecting the child, the views of the child being given due weight in accordance with the child's age and maturity" [15]. If we understand that the school is a place of participation, of shared experiences, because the human being develops in community, and because the school and the trinomial educator-educator-educational relationship is the result of human thought, it cannot be done if it is not of one another, of others among others [16]. Thus, with the school as an issue which affects students, as a democratic and participatory essence, it is imperative that it receives and attends to students' opinions and demands.

The project Gira por la Infancia [17] is a social experience that, promoted by the Independent Council for the Protection of Children and numerous social organizations, aims to share good practices on child and adolescent participation worldwide. In this sense, schools associated to the UNESCO have also shared testimonies from students and teachers around the world about what they have done in the face of school and university closures [18]. Gira 
por la Infancia 2020 has focused its interest on school and education, trying to respond to the Sustainable Development Goals 4: "Ensuring inclusive, equitable and quality education and promoting lifelong learning opportunities for all"; 10: "Reducing inequality within and between countries"; and 16: "Promoting peaceful and inclusive societies for sustainable development, facilitating access to justice for all and building effective, accountable and inclusive institutions at all levels" [19]. In this sense, it is necessary to consider, as Santos, Fernández, and Sianes state, that "the COVID-19 crisis has become a double threat to Agenda 2030. On the one hand, the impact on developing countries can be a setback in terms of poverty reduction, food security and global health, making it difficult to achieve the Sustainable Development Goals (SDGs) ... " [20] (p. 1). Children and adolescents from 22 countries in Africa, America, and Europe have shared, virtually for 11 days, their experiences, feelings, and proposals for improvement around the school and the education they are receiving during the pandemic. Education and the shaping of citizenship are sociocultural dimensions which require constant reinterpretation [21]. The project has generated a scenario of social and cultural exchange through which the participating children and adolescents have learned about different ways of life in different parts of the planet and the level of incidence of COVID-19 in each of them. In this way, education for social justice is made possible, because as Rawls said "social institutions are either fair or need to be reformed or abolished" [22] (p. 14). We work on the construction of schools where students participate by assuming active and critical roles with everything that happens around them. Democratic values based on equality, tolerance, and mutual respect are ideals that have not always come along with people. Although today society has evidently advanced in gender, culture, race, social condition, there are still many goals to be achieved. There are still exclusionary tendencies within Western democratic societies and institutions that must be eradicated [23]. For this reason, deliberative, peaceful, and constant action to eradicate them is what constitutes socially just citizenship in itself, since it produces a strengthening of identity derived from the feeling of belonging of those who were previously excluded. Therefore, social justice is understood as participation and representation of all people and especially those who belong to more vulnerable groups [24,25]. This participation must be understood in an equal manner, as indicated by Belavi and Murillo, since "that parity of participation, that is, the possibility for all to participate on equal terms with their peers, is necessary to expose justice issues that are being overlooked" [26] (p. 8). As a result, in order to work for social justice, schools, and society count on pedagogy as one of the strongest tools for social change and equity. Precisely, through a participatory and active pedagogy, the children and adolescents who have participated in this international project have been able to express their voice, so they contributed to the construction of a future generation that is active and participatory, more egalitarian, supportive, and committed [27]. This has been possible from an understanding of the human being in formation as a moral being, an aesthetic being, a political being, a spiritual being that can be nurtured through these initiatives [28]. This results in the solid growth of new generations which allows what Habermas called deliberative democracy, where citizen action through participatory axes responds to the challenges of democratic states crossed by social, cultural, ethnic diversity, economic, religious, or affective-sexual [29].

We see children and adolescents' participation as a basic right, fundamental to fully develop the autonomy and citizenship of children and adolescents, as it is provided as an essential activity in the development taking into account their dignity, respect, voice, and participation [30]. In addition, the foundations are laid for a progressive educommunication format which does not only give subjects the tools to deal with the virtual sphere of the communicative process, but also lets them interpret with a critical attitude the messages presented in the various communication channels and spheres that inflate space and cyberspace in the 21st century [31]. This results in an increase in competence that changes silence, absence, and superficiality [32] for participation and criticism in the new communication scenarios [33]. From these premises, the objective of this work is to present the data obtained in the research on education in times of COVID-19, through a 
process of child participation, for the construction of a critical, active, and participatory citizenship, in the framework of the international project Gira por la Infancia 2020.

\section{Materials and Methods}

COVID-19 has changed everyone's life, including children. They have a perception of world problems and offer a unique view as protagonists of society. Therefore, it is convenient to give prominence to their vision of the problem and from there arises the need for this project and the evaluation of the data in this study. Children and adolescents have seen their personal routines and their daily training environments modified. The perception of this change in their lives must also be taken into account and analyzed. The nature of the data that make up this study has required a qualitative research methodology [34-36]. What is more, the data, which have been collected and analyzed in relation to children and adolescents' educational situation in the times of the COVID-19, focus on their opinions and arguments. The hermeneutic exercise which is practised in this research allows, from the subjectivity of the actors present in the process, to find the understanding of the potentiality of the protagonists' experiences [37], in this case, educational and social, to assess the place of children and adolescents in the process of being or becoming active citizens. Likewise, teleologically, the application of the qualitative methodology connects the interpretation of the processes and manifestations in the form of narration of the participants with a transformative purpose of reality [38], in this case, both towards increasing the processes of citizen construction and towards increasing knowledge about the consequences that the SARS-CoV-2 pandemic has had on education from the point of view of its main protagonists: students. From the methodological sequence of this work, we also have a methodological application of dialogic learning $[39,40]$ since, through the different phases of child participation-which are specific to the project Gira por la Infancia - different children and adolescents share experiences, data, and feelings on a specific and highly topical subject. This induces different types of learning and competence development beneficial to the participants. In the essence of the dialogic learning, a protagonist consideration of the subjects prevails, giving them freedom to be able to express their opinion in adequate contexts. Likewise, it includes a high nuance of change since the exchange of ideas gives children, in this case, the power to assume as their own the approaches and proposals they undertake, which arise in the aforementioned exchange and which give rise to participation, as well as social transformation [41].

\subsection{Population and Sample}

The population in this study is composed of children and adolescents between the ages of 8 and 17. The sample is composed of 6867 children and adolescents from different countries, trying to achieve with this diversity the representation of three continents and different geographical areas with heterogeneous cultural matrices, seeking a significant internationalization: Portugal, Morocco, Peru, Colombia, Venezuela, Mozambique, Democratic Republic of Congo, Spain, Brazil, Ecuador, Senegal, El Salvador, Mexico, Cuba, Chile, Dominican Republic, Argentina, Guatemala, Mali, Italy, Nicaragua, and Uruguay. Access to the sample field has sought geographic diversity and the taking into consideration of a wide age range of the subjects.

\subsection{Procedure}

The methodological procedure followed in this work is based on a link between two specific phases as shown in Table 1.

The first of the phases has to do with an initial period of participation in the study of children and adolescents' sample. This is a period of construction of the study data and execution of the child participation processes. This phase begins with the formation of teams or working groups of children and adolescents between the ages of 8 and 17, often coordinated by a teacher or other professional from the education or social field. Each work team was a node within the child participation network which constitutes the entire project Gira por la Infancia. 
These work teams were organized around various school, educational-social, socio-cultural animation, or child vulnerability support institutions. The participation of children and adolescents has been voluntary, giving priority to the possibility of generating emancipatory processes of social activism and community development among equals. This phase places children as investigating subjects of their own reality. Table 2 shows the institutions and countries that participated as co-investigating subjects.

Table 1. Phases of the methodological design.

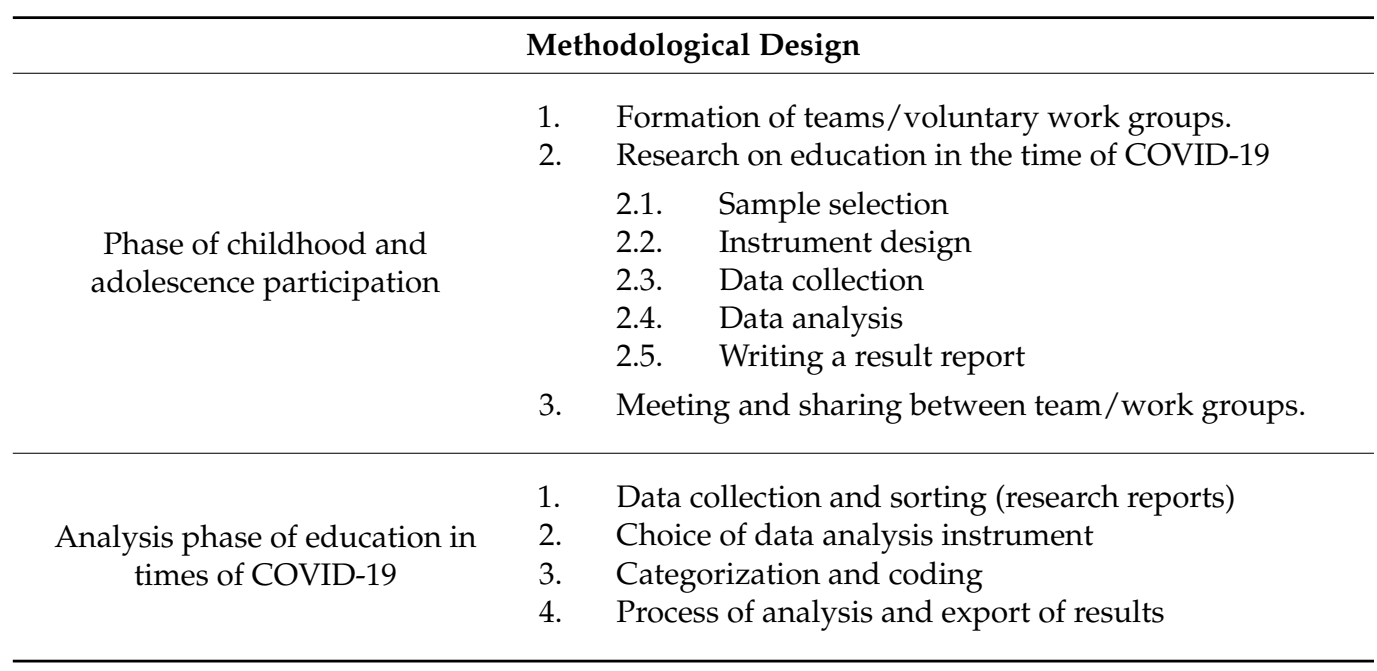

Table 2. Institutions and groups participating in the study.

\begin{tabular}{|c|c|}
\hline INSTITUTION/GROUPING & COUNTRY \\
\hline Guilherme Correia de Carvalho School & Portugal \\
\hline IMPEESA-Burjassot Scout Group & Spain \\
\hline AutodidactasGT & Guatemala \\
\hline Trinity College of Machalí & Chile \\
\hline Hebrew School of Viña del Mar & Chile \\
\hline Impacto Juvenil & Dominican Republic \\
\hline "Sangre Jóven" & Uruguay \\
\hline L'Almara-Burjassot Rhythmic Gymnastics Club & Spain \\
\hline Escobedo somos todos & Mexico \\
\hline The Frog of Chile & Chile \\
\hline Colegio Rembrandt/Pilosos de lectura & Colombia \\
\hline Fernando Soto Aparicio School, IED Bogotá & Colombia \\
\hline Educational Foundation of St. John Eudes School & Colombia \\
\hline Almahabba wal Ikhlasse Association for Orphaned Students & Morocco \\
\hline Camilo Branco School & Portugal \\
\hline Jerusalén School & El Salvador \\
\hline $\begin{array}{l}\text { Escola com Mimo. Solar do Mimo. Centro de Acolhimento de } \\
\text { Crianças em Risco. }\end{array}$ & Portugal \\
\hline Benediction & The Congo \\
\hline Mary Barreda Association & Nicaragua \\
\hline Tetouan Children's Municipal Council & Morocco \\
\hline La Joie des Orphelins Association & Senegal \\
\hline Association for the Protection of Girls and Families & Portugal \\
\hline Mi casa mi escuela & Colombia \\
\hline Sidi Idriss Elementary School & Morocco \\
\hline Sig alrededor del mundo & Brazil \\
\hline Polígono Sur High School & Spain \\
\hline Les enfants du CREREV. Foundation Mayela. & The Congo \\
\hline $\begin{array}{l}\text { Luchando por un mejor futuro } \\
\text { de los niños y niñas }\end{array}$ & El Salvador \\
\hline
\end{tabular}


Table 2. Cont.

\begin{tabular}{|c|c|}
\hline INSTITUTION/GROUPING & COUNTRY \\
\hline Center of First Reception. Caritas. Welcome to Rome & Italy \\
\hline Centro e Escola Completa Padre Joao Maria Haw & Mozambique \\
\hline Rodolfo Llinás School. Latido Llinaista & Colombia \\
\hline Le Soleil Levant. Kobalacoura & Mali \\
\hline "Choela" Association of education and culture & Morocco \\
\hline Movidos por un Abrazo & Argentina \\
\hline Villas del Progreso IED & Colombia \\
\hline Aliados Contigo-Independencia & Mexico \\
\hline Fernando de Mena High School & Spain \\
\hline García Pavón High School & Spain \\
\hline Hamlet of Huacaday & Peru \\
\hline Aliados Contigo-Alianza Real & Mexico \\
\hline Aliados Contigo-Santa Catarina & México \\
\hline Unidos por tu Voz & Mexico \\
\hline EvolutionGT & Guatemala \\
\hline Atártenos con corazón & Colombia \\
\hline Jóvenes Solidarios & Colombia \\
\hline $\begin{array}{l}\text { Amparo Juvenil de Chiquinquirá. Specialized center for the } \\
\text { reestablishment of children and adolescents' rights }\end{array}$ & Colombia \\
\hline Liceo de Coronel & Chile \\
\hline Seville Scouts Association of the Catholic Scout Movement & Spain \\
\hline Antonio García IED School & Colombia \\
\hline $\begin{array}{c}\text { Network of Organizations for the Defense of Children and } \\
\text { Adolescents' Rights }\end{array}$ & Ecuador \\
\hline Marie Curie Bilingual Countryside Gym & Colombia \\
\hline Gabi \& Sofi & Cuba \\
\hline $\begin{array}{l}\text { Renaissance Collective FT School Government. Dominican } \\
\text { Republic School }\end{array}$ & Colombia \\
\hline National Federation of High School Students & Venezuela \\
\hline $\begin{array}{c}\text { Monsignor Oscar Arnulfo Romero, Chair of Peace and } \\
\text { Human Rights. University of Los Andes }\end{array}$ & Venezuela \\
\hline Teacher Javier Martínez Arias Polytechnic & Dominican Republic \\
\hline Regional Education 11 of Puerto Plata & Dominican Republic \\
\hline El Salvador's Dreamers & El Salvador \\
\hline PAZeArte & Mexico \\
\hline
\end{tabular}

After the voluntary decision to participate, each group or team undertook the task of investigating in their environment or close context how the health crisis situation, caused by COVID-19, influenced their vital and educational development. To this end, each participating group was provided with a guide to take data from the research sample as it can be seen from the Table 3:

Table 3. Sample questions for access to research data.

Do you think it was a good idea to close schools? Why?

Have you liked the alternative education you have received? How has it been?

Do you have a computer at home? And an Internet connection?

If you don't have a computer or an Internet connection or neither of them, how have you been in contact with your teacher?

What have you missed most about the school?

Has your teacher ever asked your opinion on how to improve the alternative teaching you have received? If so, what did you say?

If you have returned to school, what do you think of the organization of the school's?

Do you wear a mask at school? If so, how do you feel about it?

Do you miss anything at school now? If so, what do you miss?

Please highlight something positive and something negative about the current school.

Can you tell a story or something important that has happened to you at home, with your family, while your school has been closed? 
Each group adapted this script to a modality of data collection instrument (face-to-face and online interview, online questionnaire, discussion groups, forums, or workshops). The way of data storage (video, sound, text) is also diverse, through platforms and applications such as Google Drive, Google Meet, Zoom, WhatsApp, or Messenger. Following qualitative analysis of the data obtained, each group prepared an outcome report which included a review of feelings and experiences during the pandemic in the past year, related to school closures, confinement, and return to school. This first phase culminated in an international meeting under the online modality through the platform Zoom in which the representatives of each of the groups or work teams shared with the rest of the teams the results of their report. Each working group included an authorized consent of the data for scientific disclosure. Likewise, each report presents an epigraph of consent so as to use the data for the same purpose. In relation to the Zoom meeting, Gira por la Infancia established an authorization protocol for participants to previously give their consent in writing so that they could participate in said initiative, as well as its broadcast on different channels and social networks. In addition, due to the geographical origin of the children and adolescents who participated in the meeting, the organization of the online meeting had the services of simultaneous translation through a French and Spanish language interpreter for the Francophone and Spanish-speaking countries. This was an important step of the project Gira por la Infancia [19] and of the methodological process which this study is based on.

The second phase was oriented towards the analysis of the experiences and feelings of the children and adolescents derived from the previous research-participation process generated by them and channeled through their reports of results. In this sense, as a result of the project Gira por la Infancia, a total of 57 reports of results from the different teams of the above-mentioned countries with presence in three continents have been analyzed as shown in Figure 1. The sum of the sample reached by each of the participating teams and the preparation of their report make up the final sample of the analysis of this study. In this way, access to the multifocal field was achieved, which was analyzed in this second phase of data processing.

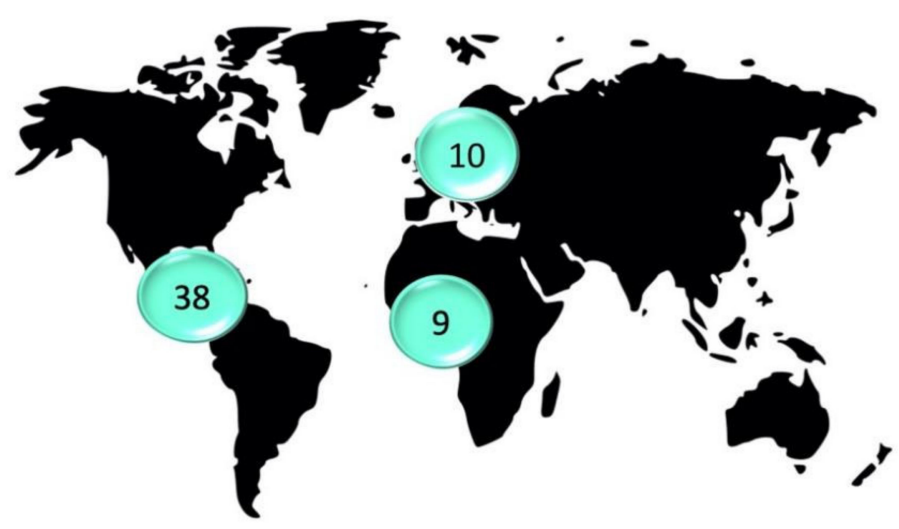

Figure 1. Representation of the number of results reports per continent.

\subsection{Analysis of the Data}

For the analytical treatment of the data, the qualitative analysis software Atlas.ti 9 was used. The use of this software allows researchers to process large amounts of data in a systematic, reliable, and effective way [42]. With the use of this tool, a codification and categorization procedure was carried out, specific to this type of methodology [43]. This required a scientific reading, that is, a process of systematic, objective, replicable, and valid reading of the reports [44]. Thus, five categories emerged by induction, which are linked to the various quotations established by analysis and numbered and duly identified by codes. Therefore, from the mentioned coding and categorization the following categories of analysis emerged: 1st thinking about school closure; 2nd thinking about alternative 
teaching; 3rd thinking about teachers; 4 th thinking about families; and 5th thinking about the return to school.

The analysis tool was used to carry out an analysis of the data collected in the different reports which were prepared on the basis of the five categories already mentioned. This also allowed an interrelationship process through networks and competitions typical of the method. At the same time, a continuous process of methodological review of the analysis was carried out through memos, which increased the coherence and stability of the data treatment and the consistency of the analysis. The export of results-thanks to the options of the software-allowed a writing of these ordered in the five categories, presenting them properly in the section dedicated to results.

\section{Results}

\subsection{Thinking about School Closure}

Results in this category address children's and adolescents' thinking on the school closure caused by the COVID-19 pandemic. From the analysis of the 57 reports, it is virtually unanimous that children saw the closure of school institutions as positive for the prevention of safety for all in different contexts. However, it should be noted that in all the reports there was a minority, who should be noted, that did not agree with the closure of schools. The following are the arguments that summarize the positions in favor of and against the closure, as stated in the reports. The Figure 2 illustrates these positions.

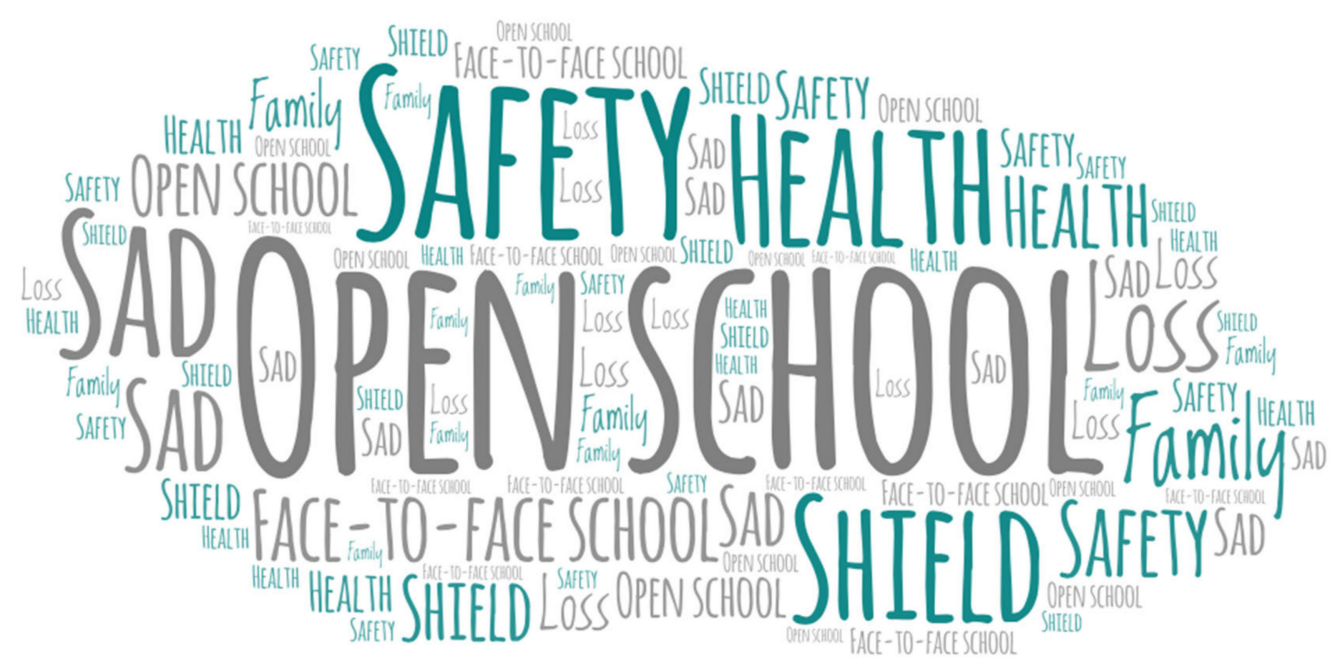

Figure 2. Cloud of terms alluding to the bipolarity of children's and adolescents' arguments in relation to opinion on the closure of schools as a consequence of coronavirus disease 2019 (COVID-19).

Arguments in favor: to avoid individual contagion, to avoid contagion to close relatives in particular, fathers, mothers, and grandparents; to reduce the spread of the disease, to avoid the ease of contagion in schools, which were not prepared to withstand the situation; to avoid the lack of control and not to aggravate the transmission with a mass contagion; to fight the virus, since they considered that children would not know how to protect themselves adequately-in some cases-and comply with the rules in the first place; to feel safe.

Arguments against: because it caused feelings and sensations of sadness, boredom, nostalgia, discouragement, confinement, anguish, and frustration; because of the lack of communication with friends and teachers, the loss of bonding with them; because of the stoppages, delays, and difficulties in the learning of the diverse subjects derived from bad teaching practices and a bad methodological design; because of not being able to go outside, to parks, to play or to do recreational and sports activities; because of monotony; because there were difficulties of connection; because of fear and uncertainty. 


\subsection{Thinking about Alternative Teaching}

The results in this category are distributed around three fundamental topics which appear with greater vehemence. In the first place, a mention of the teaching-learning processes. Generally, these have been derived from an adaptation to an alternative teaching in an online or distance modality. Although not necessarily through the use of information and communication technologies, this was the predominant route. In this way, the analysis of the reports presents a manifest bipolarity among the opinions and feelings derived from the alternative education experience as shown in Figure 3. In general, children and adolescents who had access to adequate telematic resources for online teaching consider that they did well:

"Based on our experience during this new virtual and distance modality, it has been satisfactory for us as we learn to use new digital tools and incorporate new ways of learning. Thanks to the incorporation of technological tools, we have been able to continue with our learning process" [45].

However, those who did not have regular, stable, and quality access to these resources do not have a good opinion of this alternative teaching modality. Throughout the different enclaves in which the sample of participants present their voice in this article, the diversity of ways of approaching alternative teaching moves between teaching through applications associated with the use of computers and the Internet such as Zoom, Meet, Teams, Classroom, e-mail, social networks, institutional websites; even others more dependent on the use of mobile (WhatsApp/phone calls) or television and radio. In this sense, the difference between the two moves towards one of the clearest demands by the participants: the loss of bidirectionality and feedback in the learning, and even in some cases, the total absence of it, thus preceding the isolation:

"However, here, in most villages, there is no electricity and the students have no access to radio or television. In addition, access to the internet is not national. Even in the big cities, there are families who do not have radio or television. Teachers, themselves, do not have easy access to computer materials and the Internet. So contact with teachers is not possible in our country" [46].

On the other hand, stress was a recurrent feeling, due to the adaptation to a way of carrying out the teaching process through tasks that in the voice of many participants in the study is qualified as excessive. This also poses a certain rejection by students who say they do not learn the same or miss face-to-face school:

"It was harder to understand, it took time to adapt, they had more tasks to do, it was more tiring, they were more distracted, they did not learn as much, they felt more pressure. They also missed the learning environment, the school. The distance also demanded a redoubled attention ( ... they noticed the lack of interaction with the teachers, the type of teaching did not allow them to resolve doubts personally, the practical classes, the school environment and the focus in class" [47].

Nevertheless, this is in contrast to the opinions of those who are happy to have learned new methods, new knowledge, and uses with new applications.

Secondly, there is the question of socialization, an element that repeatedly appears as a deficit and an aspect which children and adolescents missed with the closure of schools.

"The change from one level to another is very drastic, and added to this change is the lack of socialization with children or adolescents of our own age. To minimize this emotional impact, we have tried to socialize through chats and online games, which has also become a factor of conflict, because staying connected for a long time sometimes generates confrontations with our parents for the amount of time we spent there" [48].

Finally, the third topic refers to the modification of their routines, in how life with confinement and school closure changed their way of living their days, their habits, and 
customs. Thus, testimonies appear that offer a positive vision of the changes in the routine since they ask for greater flexibility to learn, greater autonomy, and freedom to organize their times of work, rest, and leisure:

"For slow-paced students, they can do their exercises which take up all their time, until they achieve the objective of the lesson, and for fast-paced students, they can do other activities even outside the school program" [49].

"I can be more relaxed at home, there is flexibility of schedules, and so I manage my time, there is not so much responsibility or demand, the classes are not followed, I learn more easily virtually. It is something I do better. I have had a lot of collaboration from my parents, I have the means and what I need at hand, I can see my mom, be with my brothers and parents, I have my comforts and I can relax after class, I have been able to train more in my sport, you can eat or play and at the same time you are in class. You do not have to bathe or to get up early" [50].

In contrast, negative views appear in relation to changes in routine, diet, and activity. They denote boredom, physical problems, stress, distortion of sleep periods, or frustration for not being able to practice their favourite sport or game:

"First, we see the transformation of the settings where they live, the houses became places of work for families and study for children, we evidence loss of habits and routines, increased sedentarism, unhealthy diets, irregular sleep patterns and increased use of screens, which can cause physical problems such as weight gain" [51].

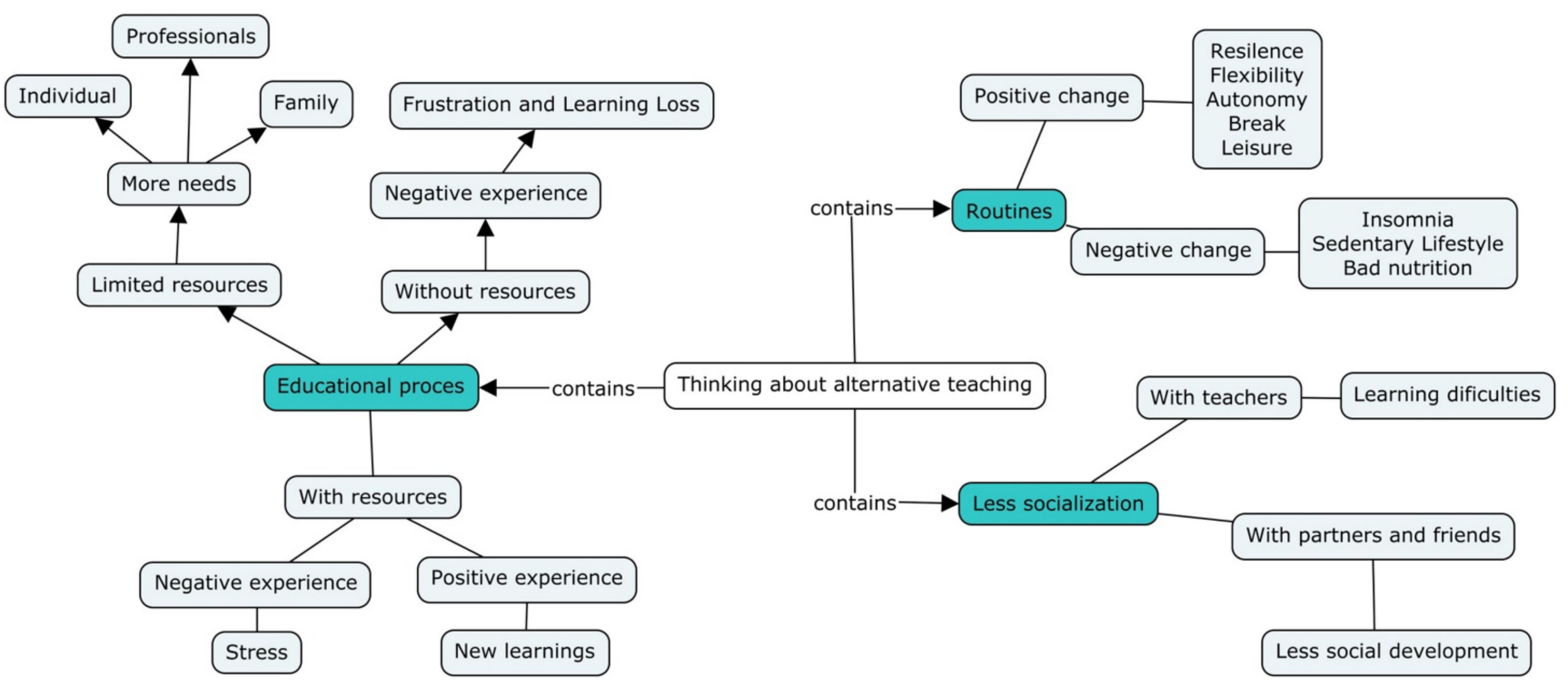

Figure 3. Outline of thinking about alternative teaching.

\subsection{Thinking about Teachers}

The educational relationship between students and teachers is a vital element in the achievement of educational processes. The pandemic and the consequent school closures undermined the standards of that relationship, which is characterized by codes, spaces, and forms established in education for years. However, the pandemic separated the educator and the student, putting barriers between them, and only in the contexts in which there was an adequate adaptation did this relationship remain more or less stable and therefore the educational process.

The analysis of the 57 reports of this study raises some highlights of that relationship. Firstly, and derived from attempts to adapt to an alternative teaching, we find the problem 
of asynchrony. In many cases, access to and management of telematic resources did not make it possible to equalize the moments of synchronous teaching-learning. As a result, this makes the time dedicated to teaching based on the sending of materials, tasks, videos, educational programs broadcast on television or radio, etc., to be assimilated by the students and resolved and sent back to their teachers. Dependence on this teaching strategy meant that many students did not adapt and felt vulnerable, confused, and delayed. In some contexts, depending on access to resources and the loss of relationship with the teacher was total.

"The virtual contact with teachers and classmates has not been enough, so we feel that there is an excess of tasks to be done without the accompaniment to solve the doubts which may arise" [52].

"Some facilities did not take alternatives and children had to resign themselves to just television, radio or self-study classes which were handed out" [53].

Secondly, and very much in line with the above, there are children's and adolescents' perception about their teachers' training. In some cases, they see that the beginnings were complex and they noticed that their teachers had neither the knowledge nor the tools to be able to cope with distance education. However, they are reflective and argue that they noticed changes for the better since they saw that, little by little, their teachers were improving and adjusting their strategies.

"The teaching methods they used were not very effective, since they did not learn, they just did their homework and sent it without understanding it well and the platforms were not effective either" [54].

"We have seen how this time teachers are more prepared with the didactics and availability, while in the previous experience, from May to June, they had seemed unprepared, there were problems related to the management of applications, downloading and uploading documents and every day there were small changes which made it more complicated to follow the classes" [55].

It is relevant that, in a high number of cases, in the reports which give voice to the thousands of children consulted, it is stated that teachers have not asked their students opinion about the variants and ways of adaptation to alternative teaching.

"At no time during the distance education process did their teachers consult them on how to improve the teaching methodology. In sum, the investigation which we carried out showed that the majority of students did not feel the support of their teachers in the process of distance education because it was full of difficulties which impeded the communication with them" [56].

In this regard, the children and adolescents who have been consulted consider that in cases where this happened, ideas could have been given which would have contributed to a better focus on educational processes.

"Their answers, in general terms, focus on the fact that they want more virtual classes as well as more time in the duration of classes, that they are more dynamic, creative, playful and fun" [57].

However, not everything is negative. In a large number of cases, the testimonies provided by the analyzed reports explain the notorious support and consideration they have received from their teachers. They have noted their concern, their interest, and their efforts to improve and not to be left abandoned and adrift. They have noted their uncertainty and have perceived within the circumstances their humanity and closeness.

"Teachers have been in contact with us virtually, supporting us in the realization of our tasks from their homes and others who visit us in our homes always taking into account the security measures" [58].

"There are conscientious teachers who are very involved with the students and who use all means to make the information available in a profitable way" [59]. 
"In general, all the classes are excellent, the teachers listen to us and take into account what we say. When they have made surveys, especially in Social Studies and English, we have been very sincere" [50].

\subsection{Thinking about Families}

The confinement and closure of schools increased the time children and adolescents spent with their families. This implied multiple and diverse moments of influence, learning, and coexistence. The result is the generation of different realities, some with a markedly positive character and others with a negative character that children and adolescents had to overcome in relation to their family environment.

From the analysis of the reports, one can see allusions to situations marked by the complexity of the moment: conflicts due to high connection time, both for doing school work and for the need for socialization of adolescents; for poor stress management on both sides; tension and lack of patience due to the health and economic uncertainty experienced by many households. In a few cases, traces of domestic violence can be pointed out. There were also infections and deaths due to the virus.

Likewise, the reports elaborated by the children and adolescents present the phenomenon of sharing work space with the parents. This situation made them value more their work and care, as well as their economic efforts so that they could continue studying, providing their homes with technological improvements. As for technology, it became common in many cases to share mobile devices or computers between parents and children (and between siblings) both for teleworking and for distance education.

"Likewise, the reports elaborated by the children and adolescents present the phenomenon of sharing work space with their parents. This situation made them value more their work and care, as well as their economic efforts so that they could continue studying, providing their homes with technological improvements. As for technology, it became common in many cases to share mobile devices or computers between parents and children (and between siblings) both for teleworking and for distance education" [60].

Finally, children's and adolescents' voices express the positive aspect of sharing moments of greater richness: cooking, playing an instrument, dancing, the help received with homework, or learning to take responsibility for aspects of the home. All of this generated greater unity among family members, which allowed them to have greater feelings of care, protection, and emotional balance. This implied a learning of high vital significance which translated into a gain in value of what the family means.

"A lot of times we had to turn to our parents, who have made a great effort to continue working and meeting our demands. They have played the role of teachers, parents and also friends. That is something we believe has been positive. The confinement has made us spend more time with our families and enjoy ourselves, that we never have much time to spend together. This has also led us to think that there are children who, if they are not treated well at home, will not have had as much fun as in our case" [61].

\subsection{Thinking about the Return to School}

After a period of stabilization of infections preceded by a long confinement, schools were reopened in many countries. This generated in children and adolescents different feelings and lived experiences.

The data which have been obtained show that participants found it positive to return to the classroom, especially with items related to the reunion and coexistence, in addition to resuming social relations, physical contact, and proximity.

Although individual protective measures, such as masks, make them uncomfortable, most are aware of the need to wear them. As citizens, they have learned the need to wear this individual and collective protection resource. 
Likewise, many of them still feel fear for the situation and, in some cases, they ask for more attention to be paid to the correct fulfillment of the measures and open the door to a semi-presential teaching prolonged in time. Many reports allege a perception of security upon return, with certain minority exceptions that disagree and ask for a safer school, with more hygienic and control measures to avoid contagion.

\section{Discussion}

As we have seen in the presentation of results, the data obtained allow us to analyze children's and adolescents' voices based on two study variables: COVID-19 and education. Through the international project Gira por la Infancia 2020, a process of child participation has been generated for the construction of a critical, active, and participatory citizenship. Precisely, students' participation, voice, and experience in relation to the five main categories of analysis demonstrate the success of the project.

The validity of the results is supported by the strength of the method. In this sense, pedagogical hermeneutics is an activity oriented to the interpretation and global understanding of the facts, in our case, educational. Moreover, we look for the decision making to alter and transform the practice.

The results which have been obtained have been interpreted from the socio-critical paradigm, using pedagogical hermeneutics as a method as well as common validation indicators, with the aim of achieving certain objectivity in pedagogical research [62], but understanding this objectivity as intersubjectivity, as we look for balance and equity between the interpretation of the data obtained and the facts along with the testimonies [62]. Through children's and adolescents' participation, the premise that has guided the entire research process is fulfilled: children's participation and voice.

These results meet the initial objectives, by achieving the idea of knowing the reality based on the information obtained from the people studied. With the results obtained, children and adolescents have detected weaknesses and strengths in relation to the educational processes experienced during the COVID-19 pandemic. Therefore, information based on the participants' contribution and empowerment has been generated, as well as the evolution of the events.

In relation to the first category 2 (1. Thinking about the school closure), the data obtained show that two clearly differentiated visions are perceived among the participants: the majority of them have chosen the vision of security through school closure, and the minority has chosen the vision of continuity in favor of keeping schools open. From the arguments of both sides, a search for certainty and, of course, for educational answers can be deduced which, in the case of those who are against the closure of the schools, had to do with a more complex and difficult experimentation with distance learning and distance between equals. Thus, this category of analysis is related to all the others, but especially to the fifth (5. Thinking about the return to school), since through the analysis of the data in the reports, we can see that the progressive return to school with high hygiene measures has been positive for children and adolescents. The meeting and coexistence have generated happiness. The absence of socialization exposed as fatal in previous sections is more or less made up for by the face-to-face meeting in a "new school". However, physical contact and displays of affection typical of a pre-pandemic situation are missed.

The data obtained from category 2 (2. Thinking about alternative teaching) and category 3 (3. Thinking about teachers) show the nostalgia in this sense for participating in sport, recreation, or academic activities which they share with their peers. Teachers and educational professionals are also mentioned in this highlighted socialization deficit. Children and adolescents point out that they miss the personal and live treatment-usual in other circumstances-underlining the loss of nuances in the educational relationship that caused the confinement. Undoubtedly, the lack of access to efficient online communication, as previously mentioned, aggravated this situation in certain contexts. As can be seen throughout the results presented in this category, children experience adaptation processes without underestimating the difficulties encountered along the way. In addition, on the 
other hand, it points out what the physical and psychological consequences of this event are. Perhaps, as it has been pointed out above, the school has lost an opportunity for change, and the educational system and the school as an institution have once again demonstrated that, despite the great crises which have struck humanity, traditional methods remain practically immovable at their base [63], because the results show that there has not been a thoughtful move to online teaching, but rather a premature, accelerated one, and in spite of the good will of teachers, without adequate preparation and without the necessary pedagogical reflection to undertake the move to virtual teaching environments with due success. Children and adolescents, along with teachers, had to change their forms and practices of teaching-learning significantly, which were different from those to which they were accustomed, meaning a change in their routines that they needed to learn [3]. New spaces and new times were intertwined with isolation and the feeling of school desertion. It was practically, at best, a transfer of the old models of direct instruction from the blackboard to the screen. This is one of the most interesting results of this research, since with the data which has been obtained it is possible to prove the importance students give to good teaching practices, especially in the relationship between bad teaching practices and the motivation and students' adaptation to the new teaching environments. This is because teachers, aside from generating the favorable conditions for competent teaching-learning, must also offer a safe and attractive learning environment, overcome students' problems, and work to eradicate social and school exclusion $[64,65]$.

Finally, in relation to the analysis of category 4 (4. Thinking about families), the data obtained demonstrate the importance and value of the first nucleus of socialization of the human being, by offering information about the recognition of family ties, the support received during confinement, time sharing, and the personal growth and evolution that it meant in the participants, building shared identities and growing in humanity and otherness.

Despite the limitations of this study, among which we can list the absence of children and adolescents from other continents, the difficulty of participation among the most vulnerable children, the digital gap, or the cultural differences among children from very different countries, we believe that the data obtained and the number of participants are a significant international sample of an emerging reality, which relates to the participation and empowerment of children and adolescents as subjects of law. Thus, the data obtained, coming from participants from 22 countries and 3 continents, can be extrapolated to other regions with a similar situation, and show that children and adolescents, when given a voice and allowed to express themselves, offer an important vision about the education that is their concern and, for the sake of social and educational justice, it must be taken into account, listened to, and above all assumed, since education is a participatory, democratic activity that provides equal opportunities, not only for learning, but also for getting involved in social situations, for living experiences, and positive relationships among children and adolescents [66].

\section{Conclusions}

The project Gira por la Infancia 2020 has among its objectives to promote an active and valuable participation of children and adolescents, in the construction of a collective identity, critical and participatory. Hence, a new reality is built, but also of empowerment and confrontation, resistance to injustice, and social, cultural, and political activism based on the construction of participatory and cooperative alliances [7]. The data and the level of participation in Gira por la Infancia 2020 confirm the importance of collective, universal, diverse, and heterogeneous participation, confirming the hypothesis that diversity in participation and plurality of approaches shows that education and knowledge are not homogeneous, but influenced by culture and context, because homogenization does not help to observe or explain what is happening [67], but it is diversity, equity, and cooperation that guarantee the right to education and participation and social justice. This study has allowed the participation of children and adolescents since it has introduced them to the 
data collection processes for research. The diversity of the sample has been possible due to the voluntary participation of educational and social institutions and organizations in the data collection process, which places this study as a platform for connection and strengthening of scientific and social activity among childhood, since it gives it a prominent role in the mechanisms that seek to analyze their situation in relation to the topic studied.

One of the main conclusions of this study is based on the evidence that, in spite of the problems and difficulties pointed out by the participants, the learning opens the way, it is informal, it is shared, and it advances, learning from the difficulties, delocalizing the educational processes, in a continuum where participation and change of contexts and daily and exclusive practices of the pre-pandemic school have evolved into participatory learning, in which, through cooperation and participation, knowledge, information, and learning have been dispersed and redistributed, and have built new and potential proactive educational agents in each student [68]. Perhaps this active, critical, and participatory empowerment of children and adolescents is one of the great opportunities in educational matters which COVID-19 has left, if we know how to appreciate and use it. The analysis of the reports made by children and adolescents shows a reflective knowledge about the phenomena of school closings derived from the problem of control of contagions by the subjects. Children and adolescents present messages endowed with sincere criticism that may well serve educators and educational scientists to implement changes in the educational adaptation processes to the current health reality.

The data obtained in this study will be useful for future research from the perspective of child participation, as it emphasizes research with children and adolescents on the idea of building an active, critical, and participatory identity of children and adolescents and their empowerment as agents of change. The data offered here show an interesting field of work, and the internationalization of the participants guarantees the possibility of extrapolating the results to advance future research.

Children's and adolescents' participation in the international project Gira por la Infancia 2020 shows the importance of giving voice to all actors, but especially to children and adolescents, as they will be the men and women of the future. If education seeks to improve human beings, we must ask ourselves, from a critical pedagogy, what kind of people we want to build, and in that sense, one of the main objectives of education is the construction of an active, useful, participatory, and fair citizen, a citizen who builds a better society [27]. We believe that projects like the one which has been presented in this work contribute to the construction of a better world, more focused on human beings. The data presented here evidence the need to change the focus of research on children and adolescents to research with them.

Among the conclusions of this article, we highlight the importance of giving students a voice in a shared and democratized construction of education. The participants in this project have demonstrated, through participation and their voice, to empower themselves for a critical citizenship in the face of the loss of social rights and the increase of inequalities with cuts in investments in social, cultural, and educational public policies [30]. Understanding children and adolescents, considering them as peers in their participation processes, is one of the great strengths of this study.

Justice is democratic, but in most cases, it is taken for granted and obvious, when in reality the relationship between democracy and social justice implies minimum conditions which are needed and complementary. Social justice is possible from participation under equal conditions, fulfilling the conditions of fair redistribution, equal status, real and equal representation, and critical social activism [26]. Precisely, the data obtained in this study demonstrate the fulfillment of these minimum conditions. However, taking into account the voice of children, alternative education with a predominantly digital nature has not reached all places equally. Children and adolescents have had this study as a means for their voice to be heard in the scientific sphere and in this case, their voice presents an urgent call about a certain inequality that must be obeyed with haste if we want to obtain a truly fair and equitable education in the world. 
The world is changing, and in this change, we have the opportunity to build new participatory and socially equitable identities. In this change, the predominant presence of educational technology is a fact. Without mortgaging educational equity, people should employ methods for educommunication or media education that help the citizen enrichment we are talking about [69]. The communication scenarios have changed and the omnipresence of the network is an evidence. For this reason, this work has also raised the idea of building critical citizenship in online training formats. It is about promoting the development of skills for the defence of one's own opinion, the identification of problems, and the drawing of strategies to solve them in a collaborative way [70]. The apparent unlimited access to information sources requires a group of competencies that derive in a filtering process and a mature approach that does not lose sight of the democratic and social equity horizon to which contemporary civilizations aspire [71]. Children and adolescents, with their voice and involvement, show that they are subjects of rights, co-authors of their own learning processes. The school must take advantage of this potential to adapt to the change that its students demand, assuming an educational teleology that overcomes the contradiction of education, that is, that resolves the dichotomy between what education aspires to be, and what it really is [72]. In this study, children and adolescents have shown signs of maturity, having to overcome circumstances such as isolation, lack of socialization, and the deficit in much learning, which has generated stress and physical and mental health problems. However, they have understood the efforts of many of their teachers and their families, which has increased the degree of maturity reached. The school opening and the new horizon that is presented should take advantage of this leap in maturity and move towards a more democratic and activist school exercise. This will generate a more sustainable school full of vitality as the communication flows between educational actors and agents will be enriched. This study has raised this from its design, from its methodological execution, and now from its presentation of results.

Finally, it is optimal to warn of the possible limitations that always accompany a research work. The phenomenon of children's participation in educational and social research processes demands the conscious task of offering clarity and rigor. In this sense, it has been sought to specify each of the phases carried out in this study so that the reader can know how the research and participation processes of children pose a challenge to the consistency of the method. However, the objective of this work gives stability to the research, allowing a process of participation and child empowerment not usually seen with high representation to be realized. Likewise, the main topic, COVID-19, poses a challenge such as the constant updating of its status in science and culture today. This study has sought to approach this topic from one of the sectors of the affected population with less emphasis on health, which broadens the range of vision on other phenomena associated with this virus, such as education. Other significant limitations of this research are found, on the one hand, in the difficulty in accessing authorizations for the transfer of data because the subjects investigated are minors, and on the other, the scarce resources to collect information in certain countries and geographic areas with lower incomes.

To conclude, the most relevant contribution of this article is found in the opinions on education and school in times of pandemic, of children and adolescents, not only from different countries and continents, but also from different social and cultural realities. The results obtained in the research carried out as a proposal for a project to promote child participation include certain voices of childhood and adolescence that, in their day-today life, do not usually have opportunities to express themselves, be heard, and, most importantly, be taken into account. As the research arose in the context of a social project, open to the world with the support of collaborating organizations, it has been possible to access places with scarce resources, both in cities and towns. The variety of perspectives collected in this study offer a broad vision of the experiences and feelings that, regarding the closure of schools and distance education, children and adolescents have lived in different corners of the planet. In this way, science and social advocacy actions promoted 
by non-profit entities go hand in hand to try to respond to the great educational challenges posed by the COVID-19 pandemic.

This work does not end here, as we are aware of future lines and possibilities for research. In this sense, the international project Gira por la Infancia 2021 is already being built, which assumes the challenge of promoting participation actions and active citizenship, where children and adolescents promote research processes that help to know the proposals that their peers propose for designing schools that truly serve life. These proposals will be shared and debated with adult experts at the 3rd World Congress on Children and Adolescents [73].

Children and adolescents have shown that, if we give them a voice, if we offer them participation in their education, despite the limitations and problems related to COVID-19, we will favor significant educational processes and an equitable reconstruction of social justice, participation, and active citizenship. We are strongly convinced that this is the way to build other worlds and other new realities with children and adolescents based on social justice.

Author Contributions: Conceptualization, methodology, software, validation, formal analysis, investigation, data curation, writing — original draft preparation, writing - review and editing, visualization, supervision, project administration, A.S.J.H., J.C.-M., and M.M.-S. All authors have read and agreed to the published version of the manuscript.

Funding: This research received no external funding.

Conflicts of Interest: The authors declare no conflict of interest.

\section{References and Notes}

1. Adverse Consequences of School Closures. More on UNESCO's COVID-19 Education Response. Available online: https: / / es.unesco.org/node/320395 (accessed on 23 December 2020).

2. Cáceres-Muñoz, J.; Jiménez, A.S.; Martín-Sánchez, M.A. Cierre de Escuelas y Desigualdad Socioeducativa en Tiempos del Covid-19. Una Investigación Exploratoria en Clave Internacional. Rev. Int. Educ. Justicia Soc. 2020, 9, 199-221. [CrossRef]

3. Guizzo, B.S.; Marcello, F.; Müller, F. A reinvenção do cotidiano em tempos de pandemia. Educ. Pesqui. 2020, 46, e238077. [CrossRef]

4. Al Comenzar un Nuevo año Académico, la UNESCO Advierte Que Sólo un Tercio de los Estudiantes Volverán a la Escuela. Available online: https: / / es.unesco.org/news/al-comenzar-nuevo-ano-academico-unesco-advierte-que-solo-tercio-estudiantesvolveran-escuela (accessed on 19 December 2020).

5. Rodríguez, S. Medidas para la conciliación de la vida laboral y familiar ante la emergencia sanitaria por COVID-19. Derecho Relac. Labor. 2020, 4, 449-472.

6. Hernández, A.L.; González, P. La conciliación no existe y las madres lo sabemos: Los malabarismos de las madres trabajadoras durante el Covid-19. Cad. Campo 2020, 29, 114-123.

7. Iglesias Vidal, E.; González-Patiño, J.; Lalueza, J.L.; Esteban-Guitart, M. Manifiesto en Tiempos de Pandemia: Por una Educación Crítica, Intergeneracional, Sostenible y Comunitaria. Rev. Int. Educ. Justicia Soc. 2020, 9, 181-198. [CrossRef]

8. Cabero Almenara, J.; Valencia, R. And COVID-19 transformed the educational system: Reflections and experiences to learn. IJERI Int. J. Educ. Res. Innov. 2020, 7. [CrossRef]

9. Espinosa, M.A. Covid-19, Educación y Derechos de la Infancia en España. Rev. Int. Educ. Justicia Soc. 2020, 9, 245-258.

10. Santos, J.; De Jesus, L.F.; Sealmoy, R.R.; Fajardo, R.R.C. Aprendizaje a distancia en línea en medio de COVID-19. IJERI Rev. Int. Investig. Innovación Educ. 2020, 15, 291-304. [CrossRef]

11. Francesco Tonucci: "Si el Virus Cambió Todo, la Escuela no Puede Seguir Igual”. Available online: https:/ /www.lanacion.com. $\mathrm{ar} /$ comunidad/francesco-tonucci-si-virus-cambio-todo-escuela-nid2356227 (accessed on 15 December 2020).

12. Iivari, N.; Sharma, S.; Ventä-Olkkonen, L. Digital transformation of everyday life-How COVID-19 pandemic transformed the basic education of the young generation and why information management research should care? Int. J. Inf. Manag. 2020, 55, 1-6. [CrossRef] [PubMed]

13. Lloyd, M. Desigualdades educativas y la brecha digital en tiempos de COVID-19. In Educación y Pandemia: Una Visión Académica; Girón, J., Ed.; Instituto de Investigaciones sobre la Universidad y la Educación, Universidad Nacional Autónoma de México: Mexico City, Mexico, 2020; pp. 115-121.

14. García Gómez, T. Bases del Derecho a la Educación: La Justicia Social y la Democracia. Rev. Int. Educ. Justicia Soc. 2018, 7, 159-175. [CrossRef]

15. Children's Rights Convention. Available online: https://www.ohchr.org/sp/professionalinterest/pages/crc.aspx (accessed on 26 December 2020). 
16. Zorroza Huarte, I. Trascendencia y apertura. Una imagen del hombre para nuestro tiempo. Cauriensia. Rev. Anu. Cienc. Eclesiásticas 2015, 10, 459-471.

17. International Project Gira por la Infancia 2020. Available online: http:/ / www.giraporlainfancia.org (accessed on 22 December 2020).

18. ¿Cómo Hace Frente al Cierre de las Escuelas y Universidades? Available online: https://es.unesco.org/covid19/ educationresponse/learningneverstops (accessed on 22 December 2020).

19. ONU. The Sustainable Development Goals Report 2017. Available online: https://unstats.un.org/sdgs/files/report/2017 / thesustainabledevelopmentgoalsreport2017.pdf (accessed on 27 December 2020).

20. Santos-Carrillo, F.; Fernández-Portillo, L.A.; Sianes, A. Rethinking the Governance of the 2030 Agenda for Sustainable Development in the COVID-19 Era. Sustainability 2020, 12, 7680. [CrossRef]

21. Pallarès Piquer, M.; Chiva Bartoll, Ó. El lugar del individuo en la era post-postmoderna. Sociedad, educación y ciudadanía tras la postmodernidad. Pensam. Rev. Investig. Inf. Filosófica 2018, 74, 835-852. [CrossRef]

22. Rawls, J.A. A Theory of Justice; Harvard University Press: Cambridge, MA, USA, 1971.

23. Twarog, K. Citizenship Education: Cultivating a Critical Capacity to Implement Universal Values Nationally. Sociální Pedagog. Soc. Educ. 2017, 5, 29-47. [CrossRef]

24. Fraser, N. Scales of Justice: Reimagining Political Space in a Globalizing World; Polity: Cambridge, UK, 2008.

25. Young, I.M. Responsabilidad por la Justicia; Paidós: Madrid, Spain, 2011.

26. Belavi, G.; Murillo, F.J. Democracia y Justicia Social en las Escuelas: Dimensiones para Pensar y Mejorar la Práctica Educativa. REICE. Rev. Iberoam. Calid. Efic. Cambio Educ. 2020, 18, 5-28.

27. Nikolakaki, M. The Hope of Critical Pedagogy in the New Dark Ages of Neoliberal Globalization and Imperialism. J. Crit. Educ. Policy Stud. JCEPS 2020, 18, 299-334.

28. Gil Claros, M.G. Educación y ética para una ciudadanía mundial. Boletín Redipe 2018, 7, 43-52.

29. Domínguez, H. Democracia deliberativa en Jürgen Habermas. Analecta Política 2013, 4, 301-326.

30. Mendonça, K.J.R.; Pires, F.F. A gente vinha porque queria e não porque era pressionado: Crianças e direitos de participação. Educ. Pesqui. 2020, 46, e237794. [CrossRef]

31. Gozálvez, V.; Contreras-Pulido, P. Empoderar a la ciudadanía mediática desde la educomunicación. Comunicar 2014, 21, 129-136.

32. Gardner-McTaggart, A.; Palmer, N. Global citizenship education, technology, and being. Glob. Soc. Educ. 2018, 16, 268-281. [CrossRef]

33. García Aretio, L. Bases, Mediciones y Futuro de la Educación a Distancia en la Sociedad Digital; Editorial Síntesis: Madrid, Spain, 2014.

34. Creswell, J.W. Research Design: Qualitative, Quantitative, and Mixed Methods Approaches; Sage: Thousand Oaks, CA, USA, 2014.

35. Flick, U. The Sage Handbook of Qualitative Data Analysis; Sage: Thousand Oaks, CA, USA, 2014.

36. Izcara Palacios, S.P. Manual de Investigación Cualitativa; Fontamara: Mexico City, Mexico, 2014.

37. Portilla Chaves, M.; Rojas Zapata, A.F.; Hernández Arteaga, I. Investigación cualitativa: Una reflexión desde la educación como hecho social. Rev. Univ. Salud 2014, 3, 86-100.

38. Ruedas, M.J.; Martha, J.; Ríos Cabrera, M.M.; Nieves Sequera, F.E. Epistemología de la investigación cualitativa. Educere 2009, 13, 627-635.

39. Aubert, A.; García, C.; Racionero, S. El aprendizaje dialógico. Cult. Educ. 2009, 21, 129-139. [CrossRef]

40. Zambrano-Alcívar, R.A.; Ávila-Carvajal, R.A.; Cedeño-Aguayo, J.M. Modelo pedagógico virtual sustentado en el aprendizaje dialógico interactivo. Una implementación necesaria. Polo Conoc. 2020, 5, 188-211.

41. Trilla, J.; Novella, A. Educación y participación social de la infancia. Rev. Iberoam. Educ. 2001, 26, 137-164.

42. Rodríguez Sabiote, C.; Lorenzo Quiles, O.; Herrera Torres, L. Teoría y práctica del análisis de datos cualitativos. Proceso general y criterios de calidad. Rev. Int. Cienc. Soc. Humanid. SOCIOTAM 2005, 15, 133-154.

43. Cerrón Rojas, W. La investigación cualitativa en educación. Horiz. Cienc. 2019, 9, 1-8. [CrossRef]

44. Ruiz Olabuénaga, J.I. Metodología de la Investigación Cualitativa; Universidad de Deusto: Bilbao, Spain, 2012 ; Volume 15.

45. Regional Education 11 of Puerto Plata, Dominican Republic. Results report. Project Gira por la infancia 2020.

46. CREREV, Fundación Mayela, The Congo. Results report. Project Gira por la infancia 2020.

47. Escola Camilo, Portugal. Results report. Project Gira por la infancia 2020.

48. PazeArte, México. Results report. Project Gira por la infancia 2020.

49. Escuela Sidi-Idris, Morocco. Results report. Project Gira por la infancia 2020.

50. Colectivo Renacimiento FT Gobierno Escolar. Dominican Republic School, Colombia. Results report. Project Gira por la infancia 2020.

51. Fundación Educativa Colegio San Juan Eudes, Colombia. Results report. Project Gira por la infancia 2020.

52. Aliados Contigo-Santa Catarina, México. Results report. Project Gira por la infancia 2020.

53. Autodidactas GT, Guatemala. Results report. Project Gira por la infancia 2020.

54. IES Fernando de Mena-IES García Pavón, Spain. Results report. Project Gira por la infancia 2020.

55. Centro de Primera Acogida. Caritas, Italy. Results report. Project Gira por la infancia 2020.

56. FENEEM Federación Nacional de Estudiantes de Educación Media, Venezuela. Results report. Project Gira por la infancia 2020.

57. Villas del Progreso IED, Colombia. Results report. Project Gira por la infancia 2020.

58. Luchando por un mejor futuro, El Salvador. Results report. Project Gira por la infancia 2020. 
59. Asociación Almahabba wal Ikhlasse for orphaned students, Morocco. Results report. Project Gira por la infancia 2020.

60. Liceo de Coronel, Chile. Results report. Project Gira por la infancia 2020.

61. Club de Gimnasia Rítmica L'Almara de Burjassot, Spain. Results report. Project Gira por la infancia 2020.

62. García Bravo, W.; Martín-Sánchez, M.Á. Hermenéutica y pedagogía: La práctica educativa en el discurso sobre la educación. Pulso Rev. Educ. 2013, 36, 55-78.

63. Cáceres-Muñoz, J.; Flores-Rodríguez, C. El inmovilismo de la cultura escolar en el marco de la postmodernidad. Reflexión sobre las causas. Hekademos Rev. Educ. Digit. 2017, 22, 58-70.

64. Symanyuk, E.E.; Pecherkina, A.A. A Study on the Components of Teachers' Professional Competence. New Educ. Rev. 2016, 44, 198-210. [CrossRef]

65. Plavšić, M.; Diković, M. What a Teacher Should not be Like. New Educ. Rev. 2019, 55, 246. [CrossRef]

66. Simón, C.; Barrios, Á.; Gutiérrez, H.; Muñoz, Y. Equidad, Educación Inclusiva y Educación para la Justicia Social. ¿Llevan Todos los Caminos a la Misma Meta? Rev. Int. Educ. Justicia Soc. 2019, 8, 17-32. [CrossRef]

67. Clemens, I. Decolonizing Knowledge. Starting Points, Consequences and Challenges. Foro Educ 2020, 18, 11-25. [CrossRef]

68. Esteban-Guitart, M.; Serra, J.M.; Vila, I. Informationalism and informalization of learnings in 21st century. A qualitative study on meaningful learning experiences. Soc. Educ. Hist. 2017, 6, 1-25. [CrossRef]

69. Barbas, A. Educomunicación: Desarrollo, enfoques y desafíos en un mundo interconectado. Foro Educ. 2012, 14, 157-175.

70. Lozano-Díaz, A.; Fernández-Prados, A. Educating Digital Citizens: An Opportunity to Critical and Activist Perspective of Sustainable Development Goals. Sustainability 2020, 18, 7260. [CrossRef]

71. Gutiérrez, A.; Tyner, K. Educación para los medios, alfabetización mediática y competencia digital. Comunicar 2012, 19, 31-39. [CrossRef]

72. Martín-Sánchez, M.; Flores-Rodríguez, C. Freedom and obedience in western education. J. Pedagog. 2018, 9, 55-78. [CrossRef]

73. 3rd World Congress on Children and Adolescents. Available online: www.congresomundialinfancia.com (accessed on 10 February 2021). 